\title{
Foreign aid, human capital and economic growth nexus: Evidence from Nigeria
}

\section{Oluwatoyin Abiola Fashina}

Department of Economics, Landmark University

Nigeria

fashina.oluwatoyin@lmu.edu.ng; toyin.fashina@yahoo.com

\author{
Abiola John Asaleye \\ Department of Economics, Landmark. University \\ Nigeria \\ asaleye.abiola@lmu.edu.ng; asaleyebiola@yahoo.com \\ Joseph Olufemi Ogunjobi \\ Department of Economics, Landmark. University \\ Nigeria \\ ogunjobi.olufemi@lmu.edu.ng;jolujobi@yahoo.com
}

\section{Adedoyin Isola Lawal}

Department of Banking and Finance, Landmark University

Nigeria

lawal.adedoyin@lmu.edu.ng; ladedoyin@yahoo.com

Abstract. This study investigates the link between aid and human capital in promoting economic growth of Nigeria. The study used two models; the first model was used to test the validity of the medicine model in Nigeria; while the extended model was used to investigate the effect of aid and human capital shocks on growth using Engle-Granger and Vector Error Correction Model (VECM) estimation techniques respectively. The findings from the first model suggest that persistent increase in foreign aid flows beyond a particular point (the optimal point) may adversely affect growth thus confirming the proposition of the Medicine Model. Evidence from the study's extended model indicates that growth in Nigeria is sensitive to human capital shock via education while the response from aid shock is trivial in the long run. The mechanism through which aid impacts economies is influenced by many heterogeneous factors, notably; the role played by the recipient governments is often not considered. Our implication from the obtained results is that government expenditures on education with additional inflows of aid can promote economic growth in Nigeria. However, there is also an indication that attainment of economic growth might be challenging for this aid-dependent country.

Received: October, 2017 1st Revision: January, 2018 Accepted: April, 2018

DOI: $10.14254 / 2071$ $8330.2018 / 11-2 / 8$ 
Keywords: Foreign aid, human capital, economic growth, medicine model, Nigeria

JEL Classification: F35, I29, O40, D69

\section{INTRODUCTION}

In the growth process of developing countries, emphases have been often placed on human capital development as the most robust source of economic growth (Teixeira \& Queiros, 2016; Zhang \& Zhuang, 2011). Due to the saving gap, however, investment in human capital development is far below minimum requirement in many developing countries, thus, foreign aid is often considered as an alternative instrument for the attainment of economic growth. Yet, there is little agreement on the exact list of factors behind sustained economic growth of developing countries. For instance, aid issues have received economic and political interest in the past and more recently too. There is a widespread concern among international donors to promote rapid economic development in developing economies such as Nigeria, however, despite these attempts; these developing economies are still lagging behind as compared to developed economies.

Rahman (2008) documented that aid was effective in the countries such as Uganda and Vietnam in the 1990s, Bolivia and Ghana in the 1980s, Indonesia in the 1970s, and Botswana in the 1960s, At the opposite end of the arguments are those who believe that aid has not been effective in helping poor countries to transform their economies and that it, on the opposite, has rather led to the dependency of the recipients from donors (Moyo, 2009; Killick, 2005; Brautigam \& Knack, 2004; Easterly, 2006; Lensink \& White, 2001; Brautigam, 2000; Knack, 2000). Murphy and Trep (2006) and also Duc V.M. (2006) pointed out that the impact of foreign aid on promoting economic growth has become a subject of considerable theoretical and empirical interests as well as practical importance, thus generating both debates and mixed results. Studies by some scholars showed that aid promotes growth (few among others include: Burnside \& Dollar, 2000; Dowling \& Hiemeiz, 1982; Gupta \& Islam, 1983; Hansen \& Trap, 2000; Snyder, 1993). Some other showed there is a negative relationship between aid and growth (few among others include the studies by Singh, 1985; Duc, 2006; Olabode, 2013). Scholars like Dhakal, Upadhyaya and Upadhyaya, (1996); Boone (1996); Jensen and Paldam (2003) showed that aid has no significant impact on economic growth as such. However, most of these and other studies measured aid in its disaggregated form such as food aid, debt forgiveness on loans and other forms which are not part of the development projects. These aid measures are not specific enough; perhaps this may be the reason for the stark contrast in the researchers' conclusions and policy suggestions.

In the presence of these debates, understanding the growth process is fundamental and essential for the economics of development. This study investigates the link between aid and human capital in promoting growth in Nigeria. The study used two models; the first model was used to test the validity of the Medicine model in Nigeria. This model stresses that aid works if given in moderation, and harms if taken in excess. The second model applied is the extended model used to investigate the effect of aid and human capital shocks on growth.

The rest of this paper is organised as follows: the introductory section is followed by Section 2 which presents the literature review. Section 3 discusses the theoretical framework and the research methodology. Section 4 presents the results of the analysis and the discussion of findings while Section 4 concludes. 


\section{LITERATURE REVIEW}

The relationship between aid and economic growth has been one of the most controversial issues, theoretically and empirically in literature. Doucouliagos and Paldam (2005) identified three main channels through which aid affects economic growth, these channels are Accumulation; Growth direct; and Conditional theoretical models. The Accumulation model estimated that the impacts of aid are on either savings or investment, and showed that aid has an unclear effect on accumulation. Growth direct model framework used the reduced model of the effect of aid on growth and showed that the estimates of the direct effect of aid on growth scattered considerably, and also added up to positive, but not statistically significant effect on growth. In addition, Conditional model estimates showed that the effect of aid on growth depends upon a third factor, if it is favourable, it will result in positive growth and vice versa. However, the inconclusive results of the aid-growth literature are highly undesirable. Many development scholars like Mosley (1987), Herbertsson and Paldam (2007), Rajan and Subramanian (2008), and Doucouliagos and Paldam (2008) were interested in searching for new models to explain the implication of aid on the economy.

Different output models have explained the importance of economic growth and its implications for human welfare (Dollar \& Kraay, 2002). The Solow model explained the dynamics of transition to steady state and how the low-income countries can meet up with the high-income countries. In 1960, the neoclassical growth model was central to various debates were more emphasis to explain the process of growth was attributed to Harrod-Domar model (Agarwala \& Singh, 1971; Livingstore, 1971). All these models focused on growth and its input with less attention to foreign aid. The Medicine Model, on the other hand, showed that aid works if given in moderation, and harms if taken in excess. In order words, Medicine Model includes aid with a positive sign and aid squared with a negative sign. Aid helps all countries of the world, but only to a point of optimal. Increasingly aid after optimal is harmful. Consequently, aid should be distributed proportionally to GDP and never exceed the optimal level. Medicine Model was used as a general defence for aid. Hadjimichael et al (1995) first proposed the model but the model was popularized by Tarp and Hjertholm (2000).

Empirically, single country analysis between human capital and foreign aid in promoting sustainable growth and development is still growing. In examining the relationship between aid and growth for the Spanish economy, Camps-Cura (2016) observed that there is a positive relationship between economic growth and human capital. The scholar stressed that Spain backwards in the international standard is as the result of low investment in human capital. In a related development, Gyimah-Brempony and Asiedu (2008) investigated the impact of aid on human capital formation in Less Developed Countries. The scholars examined the effects of aid on education or health sector and its implications for both enrollments in primary school and completion rate. The findings by Gyimah-Brempony and Asiedu (2008) showed that there is a positive relationship between aid and primary school enrollment and as well on completion rate for the periods examined. World Bank (2010) stressed that African Countries are faced with numerous challenges investing in human capital, in other to improve this situation and promote a knowledge basedeconomy, aid amongst other measures has been identified to achieve this goal (Meier, 2005).

Gani and Clemens (2003) investigated the relationship between foreign aid and human well-being in 65 developing economies. The scholars showed that there is a positive relationship between education aid and human well-being in low-income economies. In a similar study carried out by Moe (2008) in South East Asian countries. The scholar findings showed that there is a positive relationship between human capital development and post-secondary education. Michaelowa and Weber (2007) examined the impact of aid on education. The scholars divided education into three as follows: primary completion; secondary and tertiary. Michaelowa and Weber (2007) findings showed that there is a positive relationship between education and 
education aid but pointed out that the effects are relatively small. The scholars also emphasized on decreasing rates to scale on education aid returns.

Most of the studies focused on cross-country analysis (Duc, 2006; Fayissa \& El-kaissy, 1991; Karras, 2006; Mallik, 2008; McGillivray, 2005, Papanek, 1973 among others). Durlauf and Johnson (1995) emphasised on the problems encountered in panel studies in relation to grouping method which may arise as result of structural changes and other important factors that might not have been put into considerations. Rodrik (2003) stressed that the cross-country analyses helped to understand the general phenomenon without given insight into the processes involved. The general difference might vary in individual countries; each individual country has determinants for growth because of differences in economic structure and region (Sala-i-Martin, Doppelhofer \& Miller, 2003). Evidence has also been shown that there are mixed results in relating to the nexus of foreign aid, human capital and economic growth in the literature (Levine \& Renelt, 1992; Sala-i-Martin et al, 2003). The cross-country approach was found to be limited and not usually informative for a particular country. This may, however, be due to the assumptions made such as parametric invariance across countries among others. These assumptions made it not easy to explain the behaviour when attempting to interpret the result for a single country (Harrison, 1996; Hoeffler, 2002; Moseley, Hudson \& Horrell, 1987; Riddel, 2007 among others).

Consequently, the empirical specification approaches for most cross-country analysis may not be applicable to a single country study. Kenny and Williams (2001) pointed out that differences in growth process may not be useful in explaining the growth process over time for a single country study in panel studies. Some of the reasons given by the scholars included: differences in institution and governance; change of variables over time and time involved in growth process which can be best captured in time series data. Secondly, the technique of estimation differs, most especially time series properties are taken into consideration such as stationary of the variables and cointegration. Thirdly, the observations used for examination based on the access to data may not be appropriate for the technique of estimation. Most of the results given the periods of observation and availability of data faced numerous problems of measurement and interpretation.

Most of the single country analyses have focused on foreign aid and economic growth with less emphasis on human capital. Recent studies like: Lawal et al, (2017); Fang and Chang (2016); Fashina, (2016); Lawal et al, (2016); Teixeira and Queiro (2016), Qadri and Waheed (2014), Schundeln and Playforth (2013) and Zhang and Zhunag (2011) focused on human capital and economic growth with less emphasis on foreign aids. This study tends to fill the gap in the economic growth-determinants literature by examining the link between economic growth, human capital and aid. Also, promoting inclusive growth has been one of the main recent challenges in developing economies especially Nigeria; Asaleye, Okodua, Oloni \& Ogunjobi, (2017); Oloni, Asaleye, Abiodun \& Adeyemi, (2017). Maximizing the benefit from foreign aid human nexus can help to promote pro-poor growth for developing economies. In Nigeria, most of the studies focused on foreign aid, economic growth, foreign debt, governance, exchange rate, wages and employment; Asaleye, Olurinola, Oloni \& Ogunjobi, (2017); Isola, Oluwafunke, Victor \& Asaleye, (2016) among others. This study can be distinguished from the above studies by investigating the efficacy of Medicine Model among the nexus of aid, economic growth and human capital in Nigeria.

\section{THEORETICAL FRAMEWORK AND RESEARCH METHODOLOGY}

\subsection{Theoretical Framework}

Medicine Model uses Aid itself as the condition and it is expressed as below: 


$$
g_{i t}=\alpha+\mu h_{i t}+\omega h^{2}{ }_{i t}+\gamma_{j i t} x_{j i t}^{\prime}+u_{i t}=\alpha+\phi\left(h_{i t}\right)+\gamma_{j i t} x_{j i t}^{\prime}+u_{i t}
$$

In equation 3.1, the coefficient of aid is expected to be positive, that is, $\mathrm{E}(\mu)>0$ while the coefficient of aid squared is expected to be negative, that is, $\mathrm{E}(\omega)<0$. If these expectations hold, then the output of the estimated regression will be a maximum quadratic function. This would imply that the sign and robustness of both ' $\mu$ ' and ' $\omega$ ' in equation (3.1) are important for the model. The function $\phi\left(h_{i t}\right)$ in the third part of equation (3.1) indicates the combined effects of aid and aid squared on growth, and this shows the excess growth due to aid.

There are two policy conclusions to be drawn from the Medicine Model, these are: Aid should not be in excess; it is must exceed the optimal point. This can help various institutions to develop a framework to measure aid sustainability given this condition. The model also says that marginal aid effectiveness is:

$$
\partial g / \partial h=\mu+2 \omega h
$$

In equation 3.2, consequently, aid shares should be as equal as possible for all recipients. This is against the policy of poverty orientation of many donors, which demands that aid should be disproportionally given to the poor.

\subsection{Specification for Model 1}

Using Hansen and Tarp (2000), Conditional Medicine Model version is given as:

$$
g_{i t}=\mu h_{i t-L}+\omega h_{i t-L}^{2}+\alpha\left(x_{i t}, d_{t}\right)+u_{i t}
$$

Where $g_{i t}$ is the real growth, $h_{i t}$ denotes foreign aid, $x_{i t}$ is a set of control variables and $d_{t}$ is the fixed effect for time, the generalized version of the above model is thus given as:

$$
g_{i t}=\Phi\left(h_{i t-L}\right)+\alpha\left(x_{i t}, d_{t}\right)+u_{i t}
$$

The proponents of the model find that the coefficients of aid and squared aid (in equation 3.3) are positive and negative respectively, that is, $\mu>0$ and $\omega<0$. While in equation (3.4), the function $\Phi\left(h_{i t-L}\right)$ shows the excess growth due to aid. Considering time series analysis in this study, the model is specified as follows:

$$
\text { Growth }_{t}=\alpha_{0}+\alpha_{1} A I D_{t}+\alpha_{2} A I D_{t}^{2}+\varepsilon_{t}
$$

The rationale of using the Medicine Model is based on its ability to work on moderation and harms if taken in excess, just like most medicine (Hadjimichael, Ghura, Muhleisen, Nord \& Ucer, 1995). This model is suitable for developing countries like Nigeria where mismanagement of resources have been identified by the Authority Agency as one the reasons for the country's backwardness (EGRP, 2017). Equation 3.5 is estimated using the Engel-Granger approach. In equation 3.5, Growth $t_{t}$ is the log of real GDP, $A I D_{t}$ and $A I D_{t}^{2}$ denote ratios of foreign aid and squared foreign aid to GDP respectively are $\alpha_{0}, \alpha_{1}, \alpha_{2}$ and $\varepsilon_{t}$ denote error term, $\alpha_{1}$ and $\alpha_{2}$ are the coefficient of aid and aid square respectively.

\subsection{Specification for the Extended Model}

Meanwhile, the extended model accounts to examine the effect of aid and human capital shock are thus given as;

$$
\text { Growth }_{t}=\beta_{0}+\beta_{1} A I D_{t}+\beta_{2} \text { Hcap }_{t}+Z^{\prime} \gamma+\mu_{t}
$$

Specifically, the sign and significance of foreign aid and human capital coefficients in equation (3.6) would be essential for examining the implications of foreign aid and human capital development on 
economic growth in Nigeria. To examine how economic growth in Nigeria responds to shock to inflow of foreign aid and human capital development would be captured by Impulse Response Function (IRF) and Forecast Error Variance Decompositions (FEVDs). Equation (3.6) is modified and gives

$$
\text { Growth }_{t}=\beta_{0}+\beta_{1} A I D_{t}+\beta_{2} S S E_{t}+\beta_{3} E D U_{t}+\beta_{4} H L T H_{t}+\beta_{5} I N V R_{t}+\beta_{6} F D I_{t}+\beta_{7} T O P_{t}+\mu_{t}
$$

Where, $S S E_{t}$ denotes secondary school enrolment, which is measured as a percentage share of gross school enrolment, $E D U_{t}$ is ratio of total government education expenditure to GDP, $H L T H_{t}$ is ration total government health expenditure to GDP, $I N V R_{t}$ is ratio of real investment to GDP, $F D I_{t}$ is ratio of foreign direct investment to GDP while $T O P_{t}$ is the ratio of trade openness to GDP'. Other variables in equation (2.7) remain as earlier defined and the theoretical a-proiri expectation of the study is thus represented as follow: positive relationship between Growth and AID, SSE, EDU, HLTH, INVR, FDI, TOP and negative relationship with AID $^{2}$.

The extended model (equation 3.6) is estimated using VECM estimation technique. According to Hamilton (1995), the system of interdependent between aid and economic growth relationships can be examined using unrestricted Vector Autoregressive (VAR) model. However, unrestricted VAR requires that the time series to be stationary. If the time series are not stationary and become stationary after first differencing then the restricted VAR can be used which is known as Vector Error Correction Model (VECM) framework. Built on this insight, this study utilizes the VECM analytical approaches to empirically examine the link between foreign aid, human capital development and economic growth in Nigeria.

The VECM model specification for this study is specified as below:

$$
\begin{gathered}
\Delta \text { Growth }_{t}=\alpha_{0}+\sum_{t=1}^{n} \lambda_{k} \alpha_{k, t-1}+\sum_{t=1}^{n} \alpha_{1 t} \Delta \text { Growth }_{t-1}+\sum_{t=1}^{n} \alpha_{2} \Delta Y_{t-1}+\varepsilon_{1 t} \\
\Delta \text { Hcap }_{t}=\beta_{0}+\sum_{t=1}^{n} \lambda_{k} \beta_{k, t-1}+\sum_{t=1}^{n} \beta_{1 t} \Delta \text { Hcap }_{t-1}+\sum_{t=1}^{n} \beta_{2} \Delta Y_{t-1}+\varepsilon_{2 t} \\
\Delta \text { AID }_{t}=\delta_{0}+\sum_{t=1}^{n} \lambda_{k} \delta_{k, t-1}+\sum_{t=1}^{n} \delta_{1 t} \Delta A I D_{t-1}+\sum_{t=1}^{n} \delta_{2} \Delta Y_{t-1}+\varepsilon_{3 t} \\
\Delta F D I_{t}=\varphi_{0}+\sum_{t=1}^{n} \lambda_{k} \varphi_{k, t-1}+\sum_{t=1}^{n} \varphi_{1 t} \Delta F D I_{t-1}+\sum_{t=1}^{n} \varphi_{2} \Delta Y_{t-1}+\varepsilon_{4 t} \\
\Delta I N V R_{t}=\rho_{0}+\sum_{t=1}^{n} \lambda_{k} \rho_{k, t-1}+\sum_{t=1}^{n} \rho_{1 t} \Delta I N V R_{t-1}+\sum_{t=1}^{n} \rho_{2} \Delta Y_{t-1}+\varepsilon_{5 t} \\
\Delta T O P_{t}=\theta_{0}+\sum_{t=1}^{n} \lambda_{k} \theta_{k, t-1}+\sum_{t=1}^{n} \theta_{1 t} \Delta T O P_{t-1}+\sum_{t=1}^{n} \phi_{2} \Delta Y_{t-1}+\varepsilon_{6 t}
\end{gathered}
$$

In equations 3.8 to $3.13 ; \alpha_{0}, \beta_{0}, \delta_{0}, \varphi_{0}, \rho_{0}$ and $\theta_{0}$ are constant terms; $\varepsilon_{1 t}, \varepsilon_{2 t}, \ldots, \varepsilon_{6 t}$ are the error terms and assumed not to be correlated. $Y_{t}$ is the vector of the eight non-dependent variables such that for $\triangle G R O W_{t} H_{t}$ equation. ${ }^{1}$ Capital, Labour and Technology are not captured in the model. But as stipulated by the proponents of the Medicine Model, these
factors are not included in the model so as to isolate the effect of aid on economic growth. 
Given that $Y_{t-1}=A I D_{t}$, Hcap ${ }_{t}$ (i.e.SSE, EDU, and $H L T H$ ), INVR,$F D I_{t}$, and $T O P_{t}$, the term $\alpha_{k, t-1}$ represents the error correction term and $\lambda_{k}$ is the coefficient of the error correction term. In the equations, the optimal lag are given by $\mathrm{n}$, and chosen by standard diagnostic tests.

\subsection{Data Measurement and Sources}

Table 1

Summary of Data and Measurement

\begin{tabular}{|c|c|c|}
\hline Variable & Description and Measurement & Source(s) of Data \\
\hline $\ln G D P$ & Natural logarithm of real gross domestic product & $\begin{array}{c}\text { Central Bank of Nigeria } \\
\text { Statistical Bulletin. }\end{array}$ \\
\hline AID & Foreign aid was proxied by ratio of official aid and other \\
development assistance (ODA). & $\begin{array}{c}\text { World Bank, World } \\
\text { Development Indicators } \\
\text { database }\end{array}$ \\
\hline Hcap & $\begin{array}{c}\text { Human capital (Hcap) was proxied by three prominent indicators } \\
\text { of human capital development such percentage ratio of } \\
\text { secondary school enrolment to the gross value (SSE), percentage } \\
\text { share of total government education expenditure to GDP } \\
\text { (EDU) and percentage share of total government health } \\
\text { expenditure to GDP }\end{array}$ & $\begin{array}{c}\text { Central Bank of Nigeria } \\
\text { Statistical Bulletin. }\end{array}$ \\
$\begin{array}{c}\text { National Bureau of Statistics } \\
\text { various issues }\end{array}$ \\
\hline FNVR & $\begin{array}{c}\text { Real investment was measured using ratio of gross fixed capital } \\
\text { formation to GDP }\end{array}$ & $\begin{array}{c}\text { Central Bank of Nigeria } \\
\text { Statistical Bulletin. }\end{array}$ \\
\hline FOP & Frade openness is measured as the sum of import and export \\
relative to GDP & Central Bank of Nigeria \\
\hline
\end{tabular}

Data used in this study are annual figures covering the period $1984-2016$

\section{RESULTS PRESENTATION AND DISCUSSION OF FINDINGS}

\subsection{Presentation of Unit Root Test}

Summary of the ADF and PP Unit Root Test of the Series

\begin{tabular}{|c|c|c|c|c|c|}
\hline \multirow{2}{*}{ Variables } & \multicolumn{2}{|c|}{ ADF } & \multicolumn{2}{c|}{ PP } & $\begin{array}{l}\text { Order of } \\
\text { Integration }\end{array}$ \\
\cline { 2 - 5 } & Level & First Diff. & Level & First Diff. & \\
\hline Log (GDP) & $0.0579^{\mathrm{a}}$ & $-4.3952^{2^{*}}$ & $-0.0765^{\mathrm{b}}$ & $-4.3952^{\mathrm{a}^{*}}$ & $\mathrm{I}(1)$ \\
\hline AID & $-3.4864^{\mathrm{b}}$ & $-6.0464^{\mathrm{a}^{*}}$ & $-3.1871^{\mathrm{b}}$ & $-12.5904^{\mathrm{a}^{*}}$ & $\mathrm{I}(1)$ \\
\hline AID $^{2}$ & $-1.4034^{\mathrm{b}}$ & $-7.1465^{\mathrm{a}^{*}}$ & $-3.5530^{\mathrm{b}}$ & $-18.4841^{\mathrm{b}^{*}}$ & $\mathrm{I}(1)$ \\
\hline SSE & $-0.1102^{\mathrm{b}}$ & $-4.6809^{\mathrm{b}^{*}}$ & -0.1846 & $-5.7720^{\mathrm{b}^{*}}$ & $\mathrm{I}(1)$ \\
\hline EDU & $-0.6101^{\mathrm{a}}$ & $-7.0489^{\mathrm{b}^{*}}$ & $1.9729^{\mathrm{a}}$ & $-10.5618^{\mathrm{b}^{*}}$ & $\mathrm{I}(1)$ \\
\hline HLTH & $0.0894^{\mathrm{a}}$ & $-4.3483^{\mathrm{b}^{*}}$ & $-2.5991^{\mathrm{b}}$ & $-23.5596^{\mathrm{b}^{*}}$ & $\mathrm{I}(1)$ \\
\hline INVR & $-1.4887^{\mathrm{a}}$ & $-7.0927^{\mathrm{a}^{*}}$ & $-2.5994^{\mathrm{b}}$ & $-5.1938^{\mathrm{b}^{*}}$ & $\mathrm{I}(1)$ \\
\hline FDI & $-1.1528^{\mathrm{a}}$ & $-6.4615^{2^{*}}$ & $-12.8874^{\mathrm{a}}$ & $-2.7532^{\mathrm{a}^{*}}$ & $\mathrm{I}(1)$ \\
\hline TOP & $-2.2933^{\mathrm{b}}$ & $-8.9325^{2^{*}}$ & $-3.5351^{\mathrm{b}}$ & $-13.8415^{\mathrm{a}^{*}}$ & $\mathrm{I}(1)$ \\
\hline
\end{tabular}

Note: 'a' indicates a constant but without deterministic trend in the model; 'b' indicates a constant and deterministic trend in the model. The lags are selected using Schwarz info criteria. '*' shows that variable is stationary at $5 \%$. The null hypothesis for ADF and PP is that the variable is not stationary (i.e. has unit root)

Source: Authors' Computation 
Analysis of the time series data involves testing the stationarity properties of the series. This study uses Augmented Dickey-Fuller (ADF) and Phillip Perron (PP) unit root tests. Table 2 shows the summary results obtained from the respective stationarity tests conducted, all the variables were integrated of order one.

\subsection{Presentation of the Empirical Results}

Table 3

Result for Model 1

\begin{tabular}{|c|c|c|c|}
\hline \multirow{2}{*}{ Dependent Variable } & Constant & Independent Variables \\
\hline \multirow{2}{*}{$\ln$ GDP } & C & AID & AID \\
\cline { 3 - 5 } & 2.2756 & 0.00235 & $(0.0809)$ \\
\hline$p$-values & $(0.0424)$ & $(0.0443)$ & 5.207 \\
\hline \multicolumn{4}{|c|}{ Model Diagnostics } \\
\hline R-square & 0.1358 & Ljung-Box (5) & $(0.391)$ \\
\hline Durbin-Waston Stat. & 1.7935 & White Heteroscedasticity Test & 1.0479 \\
\hline
\end{tabular}

Source: Authors' computation

Table 3 presents the result of model 1 obtained from the estimation of equation 3.5. The constant term in the estimated equation is positive and significant, implying that the economy has some factors that constantly contribute positively to the development of the economy regardless of the level of foreign aid inflow. Furthermore, the coefficients of AID and $\mathrm{AID}^{2}$ are positive and negative significantly as postulated by the Medicine Model. This by implication suggests that persistence increase in aid inflows to Nigeria will promote development. However, there would be an optimal level of aid inflow that would give maximum benefit to the economy beyond which further aid inflow will dampen the economy. That is, aid inflow to Nigeria will have positive effect in the short run as described by the positive significant coefficient of AID, and have negative effect on growth in the long run as described by the negative significant coefficient of $\mathrm{AID}^{2}$. In table 3 above, it was found that the R-square, which is the explanatory power of the model, is low. This is, however, not surprising as some factors influencing growth such as capital, labour among others were not captured in the model. As stipulated by the Medicine Model, these factors are not included in the model so as to isolate the effect of Aid on economic growth. Durbin-Watson statistics is close to 2, implies no autocorrelation. Also, the residuals are not correlated as indicated by Ljung-Box statistics. The white heteroskedasticity shows that the residual series exhibit constant variance over time.

Table 4

Engle-Granger Cointegration Test

\begin{tabular}{|c|c|}
\hline ADF test statistic & -5.0422 \\
\hline Critical Values: & -3.646 \\
\hline $1 \%$ level & -2.954 \\
\hline $5 \%$ level & -2.615 \\
\hline $10 \%$ level & \\
\hline \multicolumn{2}{|c|}{ Critical values are obtainable from Mackinnon (1991) } \\
\hline
\end{tabular}

Source: Authors' computation 
The issue of spurious regression in the estimation of integrated series is addressed with Engle-Granger cointegration test. Consequently, the significance of the Engle-Granger Cointegration test result reported in Table 4 depicts the existence of long-run equilibrium relationship among economic growth and the two version of foreign aid included in the model. Since the ADF test statistics is -5.04 which is significant at the $5 \%$ level of significance, it implies that a linear combination of the 3 non-stationary series namely log (GDP), $\mathrm{AID}$ and $\mathrm{AID}^{2}$ is stationary. In other words, the variables are cointegrated meaning that the study's model is a cointegrating regression and is not spurious, even though individually the three series are nonstationary. The model was tested and satisfied the stability condition.

\subsection{Presentation of the Extended Model Results (Model 2)}

Taking cognizance of the unit root test results presented in Table 2 where it was evidently established across the two tests considered that all the concern series share common integration properties for instance I(1), which means the concern series are non-stationary. There are two prominent cointegration tests for I (I) series namely Engle-Granger cointegration test and Johansen co-integration test. The Engle-Granger test is meant for single equation model while Johansen is considered when dealing with multiple equations. The Johansen approach is used in this section to determine the number of cointegrating vectors. However, given the sensitivity of this approach to optimal lag length selection; this study determines the optimal lag length needed ${ }^{2}$.

Table 5

Summary of the Multivariate VECM Granger Causality Test Results

\begin{tabular}{|c|c|c|c|c|c|c|c|c|}
\hline $\begin{array}{l}\text { Equation } \\
\text { Variskle }\end{array}$ & $\Delta \log (G D P)$ & $\triangle A I D$ & $\triangle S S S E$ & $\triangle E D U$ & $\Delta H L T H$ & $\Delta I N V R$ & $\triangle F D I$ & $\triangle T O P$ \\
\hline$\Delta \log (G D P)$ & D.V & $\begin{array}{c}0.6825 \\
(0.4087) \\
\end{array}$ & $\begin{array}{c}1.2511 \\
(0.2633) \\
\end{array}$ & $\begin{array}{c}0.1970 \\
(0.6571)\end{array}$ & $\begin{array}{c}0.2079 \\
(0.6484) \\
\end{array}$ & $\begin{array}{c}2.8581 * * * \\
(0.0909) \\
\end{array}$ & $\begin{array}{c}6.3020 * * \\
(0.0121) \\
\end{array}$ & $\begin{array}{c}5.5239 * * \\
(0.0188) \\
\end{array}$ \\
\hline$\triangle A I D$ & $\begin{array}{c}0.9083 \\
(0.3405)\end{array}$ & D.V & $\begin{array}{c}0.4586 \\
(0.4983) \\
\end{array}$ & $\begin{array}{c}0.3392 \\
(0.5613)\end{array}$ & $\begin{array}{c}0.0404 \\
(0.8407) \\
\end{array}$ & $\begin{array}{c}0.7095 \\
(0.3996)\end{array}$ & $\begin{array}{c}2.1894 \\
(0.1390)\end{array}$ & $\begin{array}{c}2.4473 \\
(0.1177)\end{array}$ \\
\hline$\triangle S S E$ & $\begin{array}{c}0.3828 \\
(0.5361)\end{array}$ & $\begin{array}{c}0.4183 \\
(0.5178)\end{array}$ & D.V & $\begin{array}{c}0.0867 \\
(0.7684)\end{array}$ & $\begin{array}{c}1.2775 \\
(0.2584) \\
\end{array}$ & $\begin{array}{c}0.0305 \\
(0.8611)\end{array}$ & $\begin{array}{l}8.8117 * \\
(0.0038)\end{array}$ & $\begin{array}{l}10.9964^{*} \\
(0.0009) \\
\end{array}$ \\
\hline$\triangle E D U$ & $\begin{array}{c}3.6433^{* * * *} \\
(0.0563) \\
\end{array}$ & $\begin{array}{c}5.4003 * * \\
(0.0201)\end{array}$ & $\begin{array}{c}2.2571 \\
(0.1330) \\
\end{array}$ & D.V & $\begin{array}{c}1.3083 \\
(0.2527) \\
\end{array}$ & $\begin{array}{c}0.0132 \\
(0.9083)\end{array}$ & $\begin{array}{c}0.9193 \\
(0.3376)\end{array}$ & $\begin{array}{c}1.1590 \\
(0.2817)\end{array}$ \\
\hline$\triangle H L T H$ & $\begin{array}{c}12.3374^{*} \\
(0.0004)\end{array}$ & $\begin{array}{c}5.1354 * * \\
(0.0234)\end{array}$ & $\begin{array}{c}3.9240 * * \\
(0.0476)\end{array}$ & $\begin{array}{l}2.9057^{*} \\
(0.0883)\end{array}$ & D.V & $\begin{array}{c}0.0113 \\
(0.9153)\end{array}$ & $\begin{array}{c}0.2569 \\
(0.6122)\end{array}$ & $\begin{array}{c}0.0751 \\
(0.7840)\end{array}$ \\
\hline$\Delta I N V R$ & $\begin{array}{c}6.1592 * * \\
(0.0131) \\
\end{array}$ & $\begin{array}{c}0.0527 \\
(0.8184) \\
\end{array}$ & $\begin{array}{c}5.0102 * * \\
(0.0252) \\
\end{array}$ & $\begin{array}{c}0.1436 \\
(0.7047) \\
\end{array}$ & $\begin{array}{c}0.3968 \\
(0.5287) \\
\end{array}$ & D.V & $\begin{array}{c}1.8819 \\
(0.1701) \\
\end{array}$ & $\begin{array}{c}2.7748^{* * *} \\
(0.0978)\end{array}$ \\
\hline$\triangle F D I$ & $\begin{array}{c}0.0946 \\
(0.7583)\end{array}$ & $\begin{array}{c}3.3556 * * * \\
(0.0670) \\
\end{array}$ & $\begin{array}{c}0.9845 \\
(0.3211) \\
\end{array}$ & $\begin{array}{c}0.0253 \\
(0.8734)\end{array}$ & $\begin{array}{c}1.4409 \\
(0.2300)\end{array}$ & $\begin{array}{c}0.2393 \\
(0.6247)\end{array}$ & D.V & $\begin{array}{c}0.0685 \\
(0.7935)\end{array}$ \\
\hline$\triangle T O P$ & $\begin{array}{c}0.8229 \\
(0.3643) \\
\end{array}$ & $\begin{array}{c}0.1117 \\
(0.7381) \\
\end{array}$ & $\begin{array}{c}2.3231 \\
(0.1275) \\
\end{array}$ & $\begin{array}{c}0.0618 \\
(0.8035) \\
\end{array}$ & $\begin{array}{c}0.0255 \\
(0.8730) \\
\end{array}$ & $\begin{array}{c}2.2049 \\
(0.1376) \\
\end{array}$ & $\begin{array}{c}0.5401 \\
(0.4624)\end{array}$ & D.V \\
\hline$A L L$ & $\begin{array}{c}28.2283^{*} \\
(0.0002)\end{array}$ & $\begin{array}{c}15.4786^{* *} \\
(0.0303) \\
\end{array}$ & $\begin{array}{c}56.4898^{*} \\
(0.0000)\end{array}$ & $\begin{array}{c}4.4271 \\
(0.7295)\end{array}$ & $\begin{array}{l}11.9280 \\
(0.1030)\end{array}$ & $\begin{array}{c}6.6731 \\
(0.4631) \\
\end{array}$ & $\begin{array}{c}24.5027^{* * *} \\
(0.0009)\end{array}$ & $\begin{array}{c}27.5344^{* * *} \\
(0.0003)\end{array}$ \\
\hline
\end{tabular}

Note: D.V. denotes dependent variable and the probability values are in in parentheses while ${ }^{*},{ }^{*}$, and *** indicates significance at 1\%,5\% and $10 \%$.

Source: Authors' Computation

\footnotetext{
2 The lag selection and cointegration results are available will the authors and can be given on request.
} 
Table 5 presents the VECM granger causality result and it is used to evaluate the response of economic growth to foreign aid, human capital and other growth determinants in the model. From the result, there is unidirectional causality from: GDP and AID to EDU; GDP to HLTH; INVR, FDI and TOP to GDP; GDP and SSE to INVR; AID to FDI. The overall conclusion is that there is no response from human capital indicators on growth, though there is response from growth and aid on education; and health on growth was observed.

Table 6

Summary of Variance Decomposition at Ten-Period

\begin{tabular}{|c|c|c|c|c|c|c|c|c|}
\hline \multirow{2}{*}{$\begin{array}{c}\text { Percent of } \\
\text { forecst error } \\
\text { variance in: }\end{array}$} & \multicolumn{9}{|c|}{ Typical Shock in } \\
\cline { 2 - 9 } & $\boldsymbol{L o g}(\boldsymbol{G D P})$ & $\boldsymbol{A I D}$ & $\boldsymbol{S S E}$ & $\boldsymbol{E D U}$ & $\boldsymbol{H L T H}$ & $\boldsymbol{I N V R}$ & $\boldsymbol{F D I}$ & $\boldsymbol{T O P}$ \\
\hline $\boldsymbol{I o g}(\boldsymbol{G D P})$ & 77.9498 & 0.5219 & 10.6825 & 0.2098 & 0.3613 & 4.6297 & 3.0605 & 2.8775 \\
\hline $\boldsymbol{A I D}$ & 3.9940 & 84.8318 & 3.5577 & 7.3469 & 6.6530 & 1.7262 & 10.5147 & 10.0619 \\
\hline $\boldsymbol{S S \boldsymbol { E }}$ & 1.1041 & 7.6007 & 41.4997 & 11.9531 & 14.7641 & 11.3678 & 17.8372 & 16.3930 \\
\hline $\boldsymbol{E D U}$ & 5.8042 & 1.3476 & 31.6228 & 65.6835 & 62.6581 & 5.9213 & 35.4874 & 40.7567 \\
\hline $\boldsymbol{H L T H}$ & 1.2872 & 0.4494 & 1.4265 & 2.5628 & 3.6770 & 0.3358 & 8.2938 & 6.41854 \\
\hline $\boldsymbol{I N V R}$ & 2.0718 & 0.2051 & 0.1974 & 0.2146 & 0.1558 & 68.7344 & 0.0863 & 0.1401 \\
\hline $\boldsymbol{F D I}$ & 3.6437 & 0.5564 & 5.1890 & 0.5093 & 0.4610 & 1.3982 & 19.3263 & 15.9485 \\
\hline $\boldsymbol{T O P}$ & 4.1449 & 4.4865 & 5.8240 & 11.5197 & 11.2693 & 5.8863 & 5.3934 & 7.4035 \\
\hline
\end{tabular}

Source: Authors' computation using EViews7

Table 6 presents the summary of variance decomposition for tenth period horizon. In the long-run, the shock from GDP causes large percentage of variation in SSE while the shock from AID causes prominent variation in TOP than any other variable. Shocks from SSE, EDU and HLTH cause higher percentage variation in TOP, HLTH and FDI respectively. The effects of shock from HLTH and INVR are trivial on other variables in the long run. FDI and TOP shocks explain large percentage variation in SSE and EDU respectively.

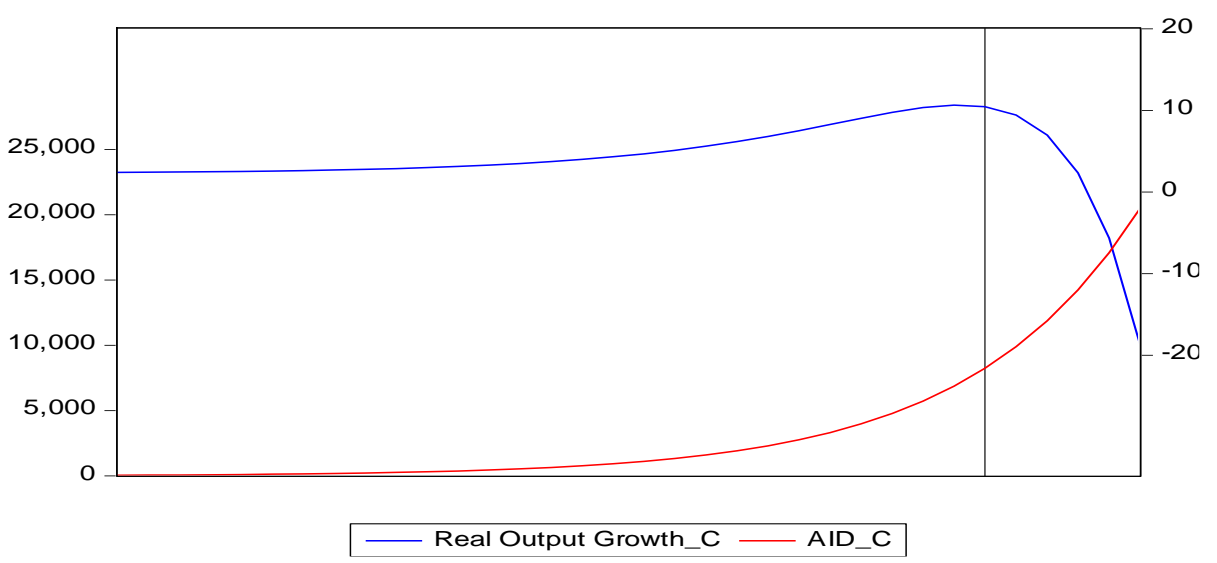

Figure 1. Combined Graph for Conditional Output Growth and Aid

Source: Authors' Computation

Given the appropriateness and the stability of the model, this study proceeds by determining an optimal level of foreign aid inflow that would give maximum benefit to the economy beyond which further aid inflow will dampen the economy. This is done by allowing the model to determine the output growth level for the Nigerian economy endogenously by allowing fixed values for the parameters of aid and aid-square 
(fixed at the value generated from the model) and the condition that aid increases persistently and exponentially. From the above figure, the real output growth increases in response to increase in foreign aid up to a point. This point happens to be the turning point where receiving of foreign aid has to be stopped; otherwise, the economy will have to suffer the consequence. This is in line with the Medicine Model. The peak aid for Nigeria as identified from this model and the output growth that would correspond to this peak aid is 10 percent. This implies that Nigeria would have to stop receiving foreign aid when its output growth reaches 10 percent as a further inflow of foreign aid beyond this level will contribute negatively to the economy. By implication, since the output growth rate of Nigeria is below 10 percent, this study concluded that foreign aid is still beneficial to Nigeria.

\subsection{Discussion of Result}

On the basis of the baseline analysis, the study shows that persistent increase in aid flows to Nigeria beyond a particular point retards growth; this actually confirms the proposition of the Medicine Model. Evidence from the extended model showed a long-run relationship among the variables under examination. Based on this result, the study proceeds to evaluate the direction of causality. From the findings, the significant response of economic growth to human capital is only viable when the latter is measure via education (EDU) and health (HLTH) expenditure. In other words, human capital when measured via secondary school enrolment (SSE) did not granger caused economic growth. It is equally important to note that the nature of causality between growth and education expenditure as well as economic growth and health expenditure was unidirectional. There was, however, an evidence of significant bi-directional causality between economic growth and domestic investment (INVR), while unidirectional between economic growth and foreign direct investment. It is also evident in the study that among other factors (aid and education not inclusive) considered responsible for growth, foreign direct investment (FDI) and trade openness (TOP) appeared the most viable for explaining growth attainment in Nigeria in the long-run.

\section{CONCLUSION}

This study examined the relationship between economic growth, foreign aid and human capital in Nigeria. The findings from the Medicine Model of the study suggest that an increasing flow of foreign aid to Nigeria would at the early stage induce economic growth up to an optimal point. However, any additional foreign aid receives beyond the optimal point will only affect the country's growth level negatively. Also, the empirical findings from the extended the model further indicate that economic growth in Nigeria would respond to human capital shock via education while the effect of shock from aid is minimal.

In the context of this study, human capital when measured via education expenditure seems more viable for explaining economic growth in Nigeria. This among others is an indication that funding of education, in addition, to support grants and inflow of aid must be given due priority by concerned authority to foster the attainment of economic growth in Nigeria. Essentially, the study revealed evidence of long-run relationship among economic growth, foreign aid, human capital and other growth determinants namely; real domestic investment, foreign direct investment and trade openness. It is also evident in the study that among other factors considered responsible for economic growth, foreign direct investment and trade openness appeared the most viable for explaining growth attainment in Nigeria as there were more statistically significant factors. However, there is an indication that attainment of economic growth might be challenging for an aid-dependent country.

In line with the findings, the following recommendations were suggested: an effective way of channeling and utilizing the inflow of foreign aid on human capital development should be embraced; there is need for the authority in charge to develop a suitable framework that would guide against the country's 
dependence on foreign aid beyond a point that may not be healthy for the economy. Also, foreign aid in form of technical assistance should be encouraged rather than financial aid in other to discourage mismanagement of resources. Technical aid will go a long way in improving human capital development and sustaining the growth and development of the economy. Finally, there is need to formulate education and health policies in order to promote investment in the sectors and maximised benefit on the sectors in the long-run.

\section{ACKNOWLEDGEMENT}

The authors are thankful to Landmark University, Omu-Aran, Kwara State, Nigeria for financial support to publish this article.

\section{REFERENCES}

Agarwala, A. \& Singh S. (1971). The Economics of Underdevelopment. Oxford University Press.

Asaleye, A.J., Olurinola, I., Oloni, E.F., \& Ogunjobi, O. (2017). Productivity growth, wages and employment nexus: Evidence from Nigeria. Journal of Applied Economic Sciences, Volume XII, Fall 5(51), 1362-1376.

Asaleye, A.J., Okodua, H., Oloni, E.F., \& Ogunjobi, J.O. (2017). Trade Openness and Employment: Evidence from Nigeria. Journal of Applied Economic Sciences, Volume XII, Summer, 4(50), 1194-1209.

Boone, P. (1994). 'The Impact of Foreign Aid on Savings and Growth', London School of Economics CEP Working Paper 1994 (677)

Brautigam, D. A. \& Knack, S. (2004). "Foreign aid, institutions, and governance in Sub-Saharan Africa", Economic Development and Cultural Change, 52(2), 255-285.

Burnside, C., \& Dollar, D. (2000), 'Aid, policies, and growth', American Economic Review, 90, 847-68, Cambridge

Camps-Cura E. (2016). The Impact of Investment in Human Capital on Economic Development: An Empirical Exercise Based on Height and Years of Schooling in Spain, Barcelona GSE Working Paper Series, Working Paper No. 897.

Central Bank of Nigeria (2016). Annual Reports and Statement of Accounts.

Dhakal D.,Upadhyaya K., \& Upadhyaya M. (1996). Foreign Aid, Economic Growth Causality, Rivita Intermazionale Di Scienze Economiche Commerciali 43, 597-606.

Dollar D., \& Kraay A. (2002). Growth is Good for the Poor, Journal of Economic Growth 7(3), 95-125.

Doucuoliagos, H., \& Paldam, M. (2005). Conditional aid effectiveness: A Meta study. University of Aarhus, Denmark. Working Paper No. 2005-14.

Doucouliagos H., \& Paldam M. (2008). Aid effectiveness on growth, a Meta study, European Journal of Political Economy $24,1-24$.

Dowling, J.M., \& Hiemenz, U. (1983). Aid, savings, and growth in the Asian region, Developing Economic 21, 4-13.

Duc, V.M. (2006). Foreign Aid and Economic Growth in the Developing Countries: A Cross- Country Empirical Analysis. Available at: http://cnx.org/content/m13519/latest/

Durlauf .S., \& Johnson P. (1995). Multiple Regimes and Cross-Country Growth Behavior. Journal of Applied Econometrics, 10, 365-384.

Economic Recovery and Growth Plan EGRP (2017). Economic Recovery and Growth Plan 2017 - 2020, Federal Republic and Growth Plan 2017 - 2020, Federal Republic of Nigeria, Ministry of Budget and National Planning. https://estateintel.com/wp-content/uploads/2017/03/Nigeria-Economic-Refom-Plan-2.pdf

Easterly, W. (2006), The White Man's Burden: Why the West's Efforts to Aid the Rest Have done so Much Ill and so Little Good, Penguin Press: New York

Fang, Z., \& Chang Y. (2016). Energy, human capital and economic growth in Asia Pacific countries : Evidence from a panel cointegration and causality analysis, Energy Economics.

Fashina, O.A. (2016). Human capital investment as a determinant of sustainable economic growth in Nigeria. International Journal of Science and Management Development, Centre for Advance Research and Development Studies, 7(2), 6470. 
Fayissa, B.,\& El-Kaissy, M.I. (1999). Foreign Aid and Economic Growth of Developing Countries (LDCs): Further Evidence. Studies in Comparative International Development.

Gani, A. \& Clemens M.D. (2003). Aid Type and its Relationship with Human Well-being, International Journal of Social Economics, 30(6), 666-688.

Gupta, K.L., \& Islam M.A. (1983). Foreign Capital, Savings and Growth. An International Cross- Section Study, Reidel Publishing Company: Dordrecht.

Gyimah-Brempony, K. \& Asiedu E. (2008). Aid and Human Capital Formation: Some Evidence, Forthcoming Africa Development/ United Nations Economic Commission for Africa Conference on Globalization, Institution and Economic Development in Africa, Tunis, Tunisia, November, 2008

Hadjimichael M.T.,Ghura, D., Mühleisen, M., Nord, R.,\& Ucer, E. M. (1995). Sub-Saharan Africa, Review of Black Political Economy 20, 31-52.

Hansen, H., \& Tarp, F. (2000), “Aid and Growth regressions”, Credit Research Paper, No. 00/7, University of Nottingham.

Harrison, A. (1996), Openness and Growth: A Time-Series, Cross-Country Analysis for Developing Countries. Journal of Development Economics, 48, 419-447.

Herbertsson T.T., \& Paldam M.( 2007). Does development aid help poor countries catch up? An analysis using the basic relations, Nationalokonomisk. Tidsskrift/Danish Journal of Economics 145, 188-214.

Hoeffler, A. (2002). "The Augmented Solow Model and the African Growth Debate", Oxford Bulletin of Economics and Statistics, 64(2), 135-158

Hamilton J. (1995). Time Series Analysis, New York, Princeton University Press

Isola, L.A., Oluwafunke, A.T.,Victor, A. \& Asaleye, A. (2016). Exchange Rate Fluctuation and Nigeria Economic Growth, EuroEconomica, Issue 2, 35

Jensen, P.\& Paldam S. (2003), "Can the New Aid-Growth Models Be Replicated?," Working Paper No.2003-17, Institute for Economics: Aarhus.

Karras, G. (2006). "Foreign aid and long-run economic growth: empirical evidence for a panel of developing countries, Journal of International Development, 18(7), 15-28.

Kenny, C. \& Williams, D. (2001). What do we know about economic growth? Or why don't we know very much? World Development, 29 (1), 1-22.

Knack S. (2000). Aid dependence and the quality of governance: a cross-country empirical analysis, World Bank Development Research Group Policy Research Working paper, No. 2396. Koyck, and H.J. Witteveen, editors, Jan Tinbergen: Selected Papers. Amsterdam.

Lawal, A.I.,Kazi, P.K., Adeoyi, O.J., Osuma, G.O., Akinmulegun, S., \& Ilo B. (2017). Capital Flight and Economic Growth: Evidence from Nigeria, Binus Business Review 8 (2), 171 - 177

Lawal, A.I.,Nwanji T.I., Asaleye A.J., \& Ahmed V. (2016). Economic Growth, Financial Debt and Trade Openness in Nigeria: An application of ARDL bound testing approach, Cogent Economics and Finance 4

Lensink, R., \& White, H. 2001. Are three negative returns to aid? Journal of Development Studies 37, 42-65

Levine, R., \& Renelt, D. (1992). A sensitivity Analysis of Cross-country regressions, American Economic Review, 82 (4): 942-963.

Livingstore, I. (1971). Economic Policy for Development, Harmondworth, UK, Penjuin

Mallik, G. (2008). 'Foreign aid and Economic Growth: A Cointegration Analysis of the Six Poorest African countries'. Economic Analysis \& Policy, 38:2.

Meiser, G.M. (2005). Biography of a Subject: An Evolution of Development Economics, Oxford: Oxford University Press

McGillivray, M. (2004). 'Descriptive and prescriptive analyses of aid allocation: Approaches, issues, and consequences'. International Review of Economics and Finance, 13(3), 275-292.

Michaelowa, K., \& Weber, A. (2007). “Aid Effectiveness in the education Sector: A Dynamic Panel Analysis”, Frontier of Economics and Globalization, 1, 357-385

Moe, T. L. (2008). "An empirical investigation of relationships between official development assistance (ODA) and human and educational development", International Journal of Social Economics, 35(3), 202-221. 
Mosley, P. Hudson, J., \& Horrell, S. (1987), Aid, the Public Sector and the Market in Less Developed Countries, Economic Journal, 97(3), 616-641

Moyo, D. 2009. Dead Aid: Why Aid is not working and How There Is a Better Way for Africa. London: Allen Lane.

NBS (2017). $\quad$ Nigerian National Bureau of Statistics, Statistics on Nigeria, Abuja

Papanek, G. F.(1973). The Effect of Aid and Other Resource Transfers on Savings and Growth in Less Developed Countries, Economic Journal 82 (3), 935-50

Olabode P. O. (2013): Foreign aid and poverty level in West African countries new evidence using a heterogeneous panel analysis, Australian Journal of Business and Management Research 3 No 4.

Oloni, E., Asaleye, A., Abiodun, F., \& Adeyemi O. (2017). Inclusive growth, agriculture and employment in Nigeria. Journal of Environmental Management and Tourism, Volume VIII, Spring, 1(17), 183 - 194

Qadri F. S., \& Waheed A. (2014) Human capital and economic growth: A macroeconomic model for Pakistan, Elsevier, Economic Modelling 42, 66-76

Rahman, M. (2008). Aid Development and Reforms: Multiplicity Methodology and Emotiveness, paper presented at SID Seminar in Dakar, January 31, 2008

Rajan, R.G., \& Subramanian, A., (2008). Aid and growth: what does the cross-country evidence really show? (first IMF WP/05/127), Review of Economics and Statistics 90, 643-651

Riddell, R. (2007), Does Foreign Aid Really Work?, Oxford University Press: Oxford

Rodrik, D. (2003), 'Growth Strategies' NBER Working paper series, No. wp10050.

Sala-i-Martin, X., Doppelhofer, G., \& Miller, R.I. (2003), 'Determinants of Long-Run Growth: A Bayesian Averaging of Classical Estimates (BACE) Approach', Paper presented at the CREIE

Schündeln S.,\& Playforth J. (2013). Private versus social returns to human capital: Education and economic growth in India, European Economic Review, Elsevier, 66, 266-283,

Singh, R.D. (1985). State Intervention, Foreign Economic Aid, Savings and Growth in LDCs: Some recent Evidence, KYKLOS, 38, 216-232.

Snyder, D.W. (1990), "Foreign Aid and Domestic Savings: A Spurious Correlation?” Economic Development and Cultural Change, 39, 175-181

Tarp, F. \& Hjertholm P. (2000). Foreign Aid and Development, Lessons Learnt and Directions for the Future, Routledge, London

Teixeira, A.A.C., \& Queirós, A.S.S (2016). Economic growth, human capital and structural change: A dynamic panel data analysis, Research Policy, Elsevier.

World Bank (2010). Building Human Capital in Africa, Human Development Africa http://siteresources.worldbank.org/INTHUMDEV/Resources/WBHDbrochureweb.pdf

World Bank (2016). World Bank Indicators, World Bank, Washington, DC

Zhang, C., \& Zhuang, L. (2011). The composition of human capital and economic growth: Evidence from China using dynamic panel data analysis, China Economic Review 22, 165-171. 